\section{Short-term effects of triiodothyronine on thyroid hormone receptor alpha by PI3K pathway in adipocytes, 3T3-L1}

\author{
Efeitos rápidos da triiodotironina no receptor de hormônio \\ tireoidiano alfa pela via PI3K em adipócitos, 3T3-L1
}

Miriane de Oliveira', Regiane Marques Castro Olimpio', Maria Teresa De Sibio', Fernanda Cristina Fontes Moretto', Renata de Azevedo Mello Luvizotto²,

Célia Regina Nogueira'

\begin{abstract}
Objective: The present study aimed to examine the effects of thyroid hormone (TH), more precisely triiodothyronine (T3), on the modulation of TH receptor alpha (TR $\alpha$ ) mRNA expression and the involvement of the phosphatidyl inositol 3 kinase (PI3K) signaling pathway in adipocytes, 3T3-L1, cell culture. Materials and methods: It was examined the involvement of PI3K pathway in mediating T3 effects by treating 3T3-L1 adipocytes with physiological $(P=10 n M)$ or supraphysiological $(\mathrm{SI}=100 \mathrm{nM}$ ) T3 doses during one hour (short time), in the absence or the presence of PI3K inhibitor (LY294002). The absence of any treatment was considered the control group (C). RT-qPCR was used for mRNA expression analyzes. For data analyzes ANOVA complemented with Tukey's test was used at $5 \%$ significance level. Results: T3 increased TR $\alpha$ mRNA expression in $\mathrm{P}(1.91 \pm 0.13, \mathrm{p}<0.001)$, $\mathrm{SI}(2.14 \pm 0.44, \mathrm{p}<0.001)$ compared to $\mathrm{C}$ group $(1 \pm 0.08)$. This increase was completely abrogated by LY294002 in $P(0.53 \pm 0.03, p<0.001)$ and $\mathrm{SI}(0.31$ $\pm 0.03, p<0.001$ ). To examine whether TR $\alpha$ is directly induced by T3, we used the translation inhibitor cycloheximide (CHX). The presence of $\mathrm{CHX}$ completely abrogated levels TR $\alpha$ mRNA in $P(1.15 \pm 0.05, p>0.001)$ and $\mathrm{SI}(0.99 \pm 0.15, p>0.001)$, induced byT3. Conclusion: These results demonstrate that the activation of the PI3K signaling pathway has a role in T3-mediated indirect TR $\alpha$ gene expression in 3T3-L1 adipocytes. Arq Bras Endocrinol Metab. 2014;58(8):833-7
\end{abstract}

Keywords

Triiodothyronine; adipocytes; TR $\alpha$; PI3K

\section{RESUMO}

Objetivo: O objetivo do presente estudo foi analisar os efeitos do hormônio tireoidiano (HT), triiodotironina (T3), na modulação da expressão de mRNA do receptor alfa (TR $\alpha$ ) de HT e o envolvimento da via de sinalização da via fosfatidilinositol 3-quinase (PI3K) em adipócitos, 3T3-L1. Materiais e métodos: Foi examinado o envolvimento da via PI3K nos efeitos do T3 nos tratamentos de adipócitos, 3T3-L1, nas doses fisiológica $(\mathrm{P}=10 \mathrm{nM})$ ou suprafisiológica $(\mathrm{SI}=100 \mathrm{nM})$ durante uma hora (tempo curto), na ausência ou na presença do inibidor da PI3K (LY294002). A ausência de qualquer tratamento foi considerada o grupo controle (C). RT-qPCR foi utilizado para analisar a expressão do mRNA. Para as análises dos dados, utilizou-se ANOVA complementada com o teste de Tukey a 5\% de significância. Resultados: OT3 aumentou a expressão de mRNA deTR $\alpha$ em $\mathrm{P}(1,91 \pm 0,13, \mathrm{p}<0,001)$ e $\mathrm{SI}(2,14 \pm 0,44, \mathrm{p}<0,001)$ em comparação com o grupo $C(1 \pm 0,08)$. Esse aumento foi completamente abolido por $L Y 294002$ em $P(0,53 \pm 0,03, p<$ $0,001)$ e SI $(0,31 \pm 0,03, p<0,001)$. Para examinar se a expressão deTR $\alpha$ foi diretamente induzida pelo T3, utilizou-se o inibidor de tradução, ciclohexamida (CHX). A presença de $\mathrm{CHX}$ reduziu os níveis de mRNA de TR $\alpha$ em $\mathrm{P}(1,15 \pm 0,05, \mathrm{p}>0,001)$ e $\mathrm{SI}(0,99 \pm 0,15, \mathrm{p}>0,001)$, induzidos pelo T3. Conclusão: Esses resultados demonstram que a ativação da via de sinalização de $\mathrm{PI} 3 \mathrm{~K}$ tem um papel importante na expressão do geneTR $\alpha$ mediada indiretamente peloT3, em adipócitos 3T3-L1. Arq Bras Endocrinol Metab. 2014;58(8):833-7

\section{Descritores}

Triiodotironina; adipócitos; TR $\alpha$; PI3K
1 Department of Internal Medicine, Botucatu School of Medicine, University of São Paulo State (Unesp), Botucatu, SP, Brazil 2 Institute of Health Sciences, Universidade Federal do Mato Grosso (UFMT), Sinop, MT, Brazil

Correspondence to:

Miriane de Oliveira

Botucatu Medical School,

Universidade Estadual Paulista Distrito de Rubião Jr s/n 18618-000 - Botucatu, SP, Brazil miriane.deoliveira@yahoo.com.br

Received on Feb/20/2014 Accepted on Aug/18/2014

DOI: 10.1590/0004-2730000003295 


\section{INTRODUCTION}

$\mathrm{T}$

hyroid hormone (TH) influences the metabolism and development of adipose tissue (AT) and modulates the proliferation and differentiation of adipocytes (1), mainly 3,5,3'-triiodothyronine (T3) (2). TH also stimulates lipolysis and lipogenesis (3) and is involved in regulation of lipid and carbohydrate metabolism in liver, skeletal muscle and heart tissues (4).

$\mathrm{TH}$ receptors (THR) are proteins that belong to the nuclear hormone receptor superfamily and originate from $\mathrm{TH}$ receptor alpha $(\mathrm{TR} \alpha)$ and $\mathrm{TH}$ receptor beta $(\operatorname{TR} \beta)$ genes $(5,6)$ located on chromosomes 17 and 3 in humans, respectively. These nuclear receptors act on certain genes according to nucleotide sequences called TH responsive elements (TRE) located in the promoter sites of target genes (7). Although THR are primarily nuclear receptors, approximately $10 \%$ are located in the cytoplasm (8). All isoforms of THR, TR $\alpha 1$, TR $\alpha 2$, and TR $\beta 1$, are expressed in white and brown adipose tissue, being TR $\alpha \mathrm{l}$ the predominant THR isoform $(9,10)$. T3 and other hormones regulate the different TR isoforms.

$\mathrm{TH}$ may function through other mechanisms than THR/TRE (11). Alternative mechanisms may be referred as a non-classical or non-genomic because initiation sites are located in the plasma membrane, such as activation of $\alpha v \beta 3$ integrin, or the cytoplasm where $\mathrm{TH}$ may activate mitogen-activated protein (MAPK) or the phosphatidyl inositol 3-kinase (PI3K) pathway. Initiation sites are proteins that are characterized as iodothyronine receptors $(12,13)$.

As lipid metabolism is closely associated with a number of health problems, the regulation of adipocytes represents an area of emerging interest. So far, TR has been implicated as a major factor in the regulation of the development and function of adipose tissue (1416). In this study it was assessed the effects of different levels of T3 (physiological and supraphysiological) on $\mathrm{TR} \alpha$ gene expression in adipocyte cell culture, 3T3-L1, by real-time PCR (RT-qPCR), during one-hour exposure. The influence of protein synthesis on regulation of TR $\alpha$ transcription by T3 and possible activation of a non-classical pathway (PI3K), by T3, to modulate this gene was also evaluated. Our observations suggest that mRNA TR $\alpha$ levels modulated by T3 depends on activation of the PI3K pathway.

\section{MATERIALS AND METHODS}

\section{Chemicals}

Isobutylmethylxanthine (IBMX), dexamethasone, insulin, cycloheximide (CHX), triiodothyronine (T3), LY294002 (LY), dimethyl sulfoxide (DMSO), sodium hydroxide $(\mathrm{NaOH})$ and Charcoal Stripped fetal bovine serum (FBS) were purchased from Sigma (St Louis, MO, USA). Dulbecco's modified Eagle's medium (DMEM), fetal bovine serum and antibiotic-antimycotic 100X solution were purchased from Gibco BRL (Grand Island, NY, USA).

\section{Cell culture and differentiation}

The experimental protocol was approved by the Ethics Committee on Animal Experiments of the Botucatu School of Medicine-Unesp (protocol $n^{0} 752$ ).

Mouse 3T3-Ll pre-adipocytes were obtained from the Cell Bank of Rio de Janeiro (Rio de Janeiro, RJ, Brazil) and grow in polystyrene 6-well plates at $37^{\circ} \mathrm{C}$ in DMEM supplemented with $10 \%$ FBS and $1 \%$ antibiotic-antimycotic $100 \times$ solution. Upon cell confluence (designated as day 0 ), differentiation was initiated with $1 \mu \mathrm{g} / \mathrm{mL}$ insulin, $1 \mu \mathrm{M}$ DEX, and $0.5 \mathrm{mM}$ IBMX in DMEM containing 10\% FBS. After a 4-day incubation, culture media was replaced by DMEM supplemented with $10 \% \mathrm{FBS}$ and $1 \mu \mathrm{g} / \mathrm{mL}$ insulin, and the cells were fed every two days with DMEM containing 10\% FBS. $3 \mathrm{~T} 3$-Ll cells were fully differentiated by day 8 . After differentiation, cells were incubated for 24 hours in DMEM supplemented with $10 \%$ charcoal stripped FBS (to deplete T3) and $1 \mu \mathrm{g} / \mathrm{ml}$ insulin. After incubation, cells were treated with physiological T3 (10 nM; P group) or supraphysiological T3 (100 nM; SI) (1719) for one hour. A non-treated group, that received $0.1 \% \mathrm{NaOH}$ (diluent T3), served as the control (C). $\mathrm{P}$ and SI groups were also treated with $\mathrm{CHX}(10 \mu \mathrm{g} / \mathrm{mL})$ (13) and LY (50 $\mu \mathrm{M})(13)$ for one hour.

LY was used to determine if the non-classical pathway (PI3K) was involved in T3 action on TR $\alpha$ mRNA levels. CHX was used to determine if T3 directly or indirectly modulates TR $\alpha$ during the one-hour exposure.

\section{Oil red 0 staining}

3T3-Ll cells were grown on 6-well plates and induced to differentiate as previously described. After an 8-day incubation (day 8), plates were washed twice with phosphate-buffered saline (PBS), fixed with 37\% formalde- 
hyde for 30 minutes at room temperature, and washed twice again with PBS. After fixation, cells were stained for two hours at room temperature with a filtered oil red O solution $(0.5 \mathrm{~g}$ oil red O (Sigma) in $100 \mathrm{~mL}$ isopropanol), washed twice with distilled water, and visualized to confirm differentiation.

\section{Gene expression}

Whole RNA was extracted from 3T3-Ll cells using Trizol (Invitrogen) according to the manufacturer's instructions. A high capacity cDNA reverse transcription kit for RT-PCR ${ }^{\circledast}$ (Invitrogen, Sao Paulo, Brazil) was used to synthesize $20 \mu \mathrm{L}$ of complementary DNA (cDNA) from 1,000 ng of whole RNA.

TR $\alpha$ (assay Mm00617505_ml - Applied Biosystems) mRNA levels were determined by real-time polymerase chain reaction (RT-qPCR). Quantitative measurements were determined with the Applied Biosystems StepOne Plus detection system using a TaqMan qPCR commercial kit (Invitrogen) according to the manufacturer's instructions. Cycling conditions were as follows: enzyme activation at $50^{\circ} \mathrm{C}$ for $2 \mathrm{~min}$, denaturation at $95^{\circ} \mathrm{C}$ for $10 \mathrm{~min}$, cDNA product amplification for 40 cycles of denaturation at $95^{\circ} \mathrm{C}$ for $15 \mathrm{~s}$, and annealing/extension at $60^{\circ} \mathrm{C}$ for $1 \mathrm{~min}$. Gene expression was quantified relative to $\mathrm{C}$ group values after normalization by an internal cyclophilin (assay Mm00434759_ml- Applied Biosystems) control using the $2^{-\Delta \Delta \mathrm{Ct}}$ method as previously described (20).

\section{Statistical analysis}

Gene expression was analyzed using analysis of variance (ANOVA) followed by Tukey's test. Data are expressed as mean \pm standard deviation. The significance level was set at $5 \%$.

\section{RESULTS}

\section{Different T3 concentrations up-regulation TR $\alpha$ mRNA by PI3K pathway}

Figure 1 shows the up-regulation of TR $\alpha$ levels in 3T3$\mathrm{Ll}$ adipocytes, and to verify PI3K pathway involvement in mediating the action of T3 on TR $\alpha$ mRNA expression the P and SI groups were treated with the PI3K pathway inhibitor LY. We showed that LY associated with $\mathrm{T}_{3}$ led to decreased TR $\alpha$ mRNA levels (Figure 1A and $\mathrm{B}$ ).
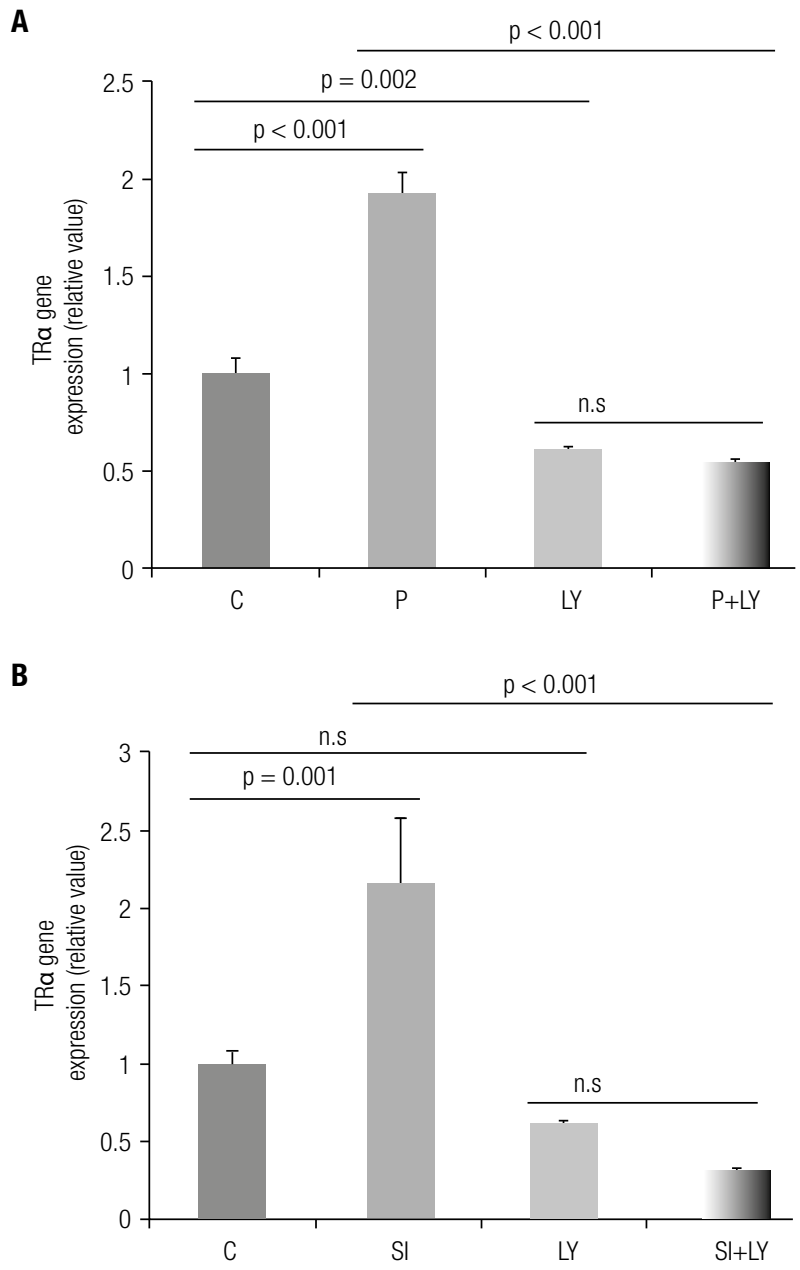

Figure 1. Effects of T3 and LY294002 on modulation of TR $\alpha$ mRNA levels in one hour. $\mathrm{P}=10 \mathrm{nM} \mathrm{T3}, \mathrm{SI}=100 \mathrm{nM} \mathrm{T3}, \mathrm{C}=$ no T3, and $\mathrm{LY}=50 \mu \mathrm{M}$ LY294002. (A) T3 influence (10 nM) on TR $\alpha$ gene expression in the presence/absence of LY. (B) T3 influence (100 nM) on TR $\alpha$ gene expression in the presence/absence of LY. ANOVA with Tukey's test. n.S. = non-significant; $n=3$ per treatment.

\section{Effect of inhibition of protein synthesis on T3- induced modulation of TR $\alpha$ mRNA levels}

3T3- $\mathrm{Ll}$ adipocytes were cultured with $\mathrm{T} 3$ at doses that influenced TR $\alpha$ mRNA levels to determine the need for protein synthesis during one hour exposure. CHX was added to the P and SI groups. Complete abrogation of the T3-induced mRNA increase by CHX indicates that the TR $\alpha$ gene is indirectly induced by $\mathrm{TH}$ and requires prior protein synthesis (Figure $2 \mathrm{~A}$ and $\mathrm{B}$ ). However, CHX alone had significant influence on TR $\alpha$ mRNA levels.

\section{DISCUSSION}

AT is a target of TH and expresses THR that are important factors in regulating tissue development and func- 
tion $(16,21)$. In this paper we evaluated AT responses to different $\mathrm{T}_{3}$ levels based on TR $\alpha$ mRNA expression without interference from systemic factors that occur in vivo. As an experimental model, we used 3T3-Ll cells (embryonic Mus musculus cells) that were differentiated in vitro into adipocytes. TR $\alpha \mathrm{mRNA}$ levels were quantified using RT-qPCR.

A

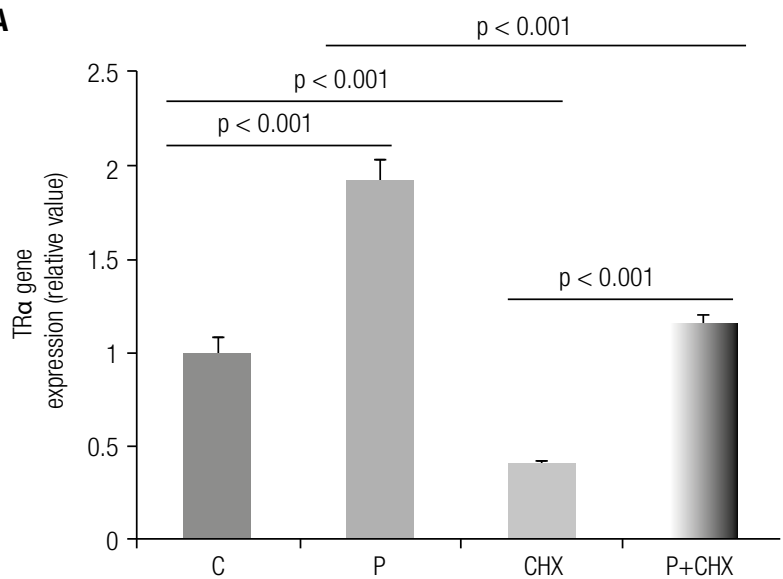

B

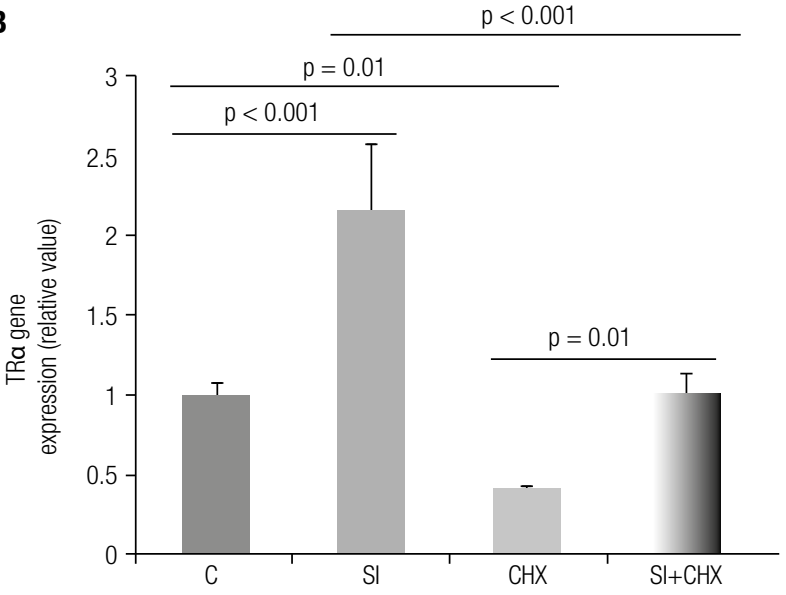

Figure 2. Effects of $\mathrm{T} 3$ and $\mathrm{CHX}$ on modulation of $\mathrm{TR} \alpha \mathrm{mRNA}$ levels in one hour. $\mathrm{P}=10 \mathrm{nM} \mathrm{T}, \mathrm{SI}=100 \mathrm{nM} \mathrm{T3}, \mathrm{C}=$ no T3, and $\mathrm{CHX}=10 \mu \mathrm{g} / \mathrm{mL}$. (A) T3 influence (10 nM) on TR $\alpha$ gene expression in the presence/absence of CHX. (B) T3 influence (100 nM) on TR $\alpha$ gene expression in the presence/absence of CHX. ANOVA with Tukey's test. n.s. = non-significant; $n=3$ per treatment.

3T3-Ll pre-adipocytes represent a well-established model for adipogenesis (22). TR $\alpha$ expression is higher than TR $\beta$ in 3T3-Ll adipocytes (18), which is in accordance with the findings of Jiang and cols. (2004) (23). Studies from our group showed that a T3 physiological and supraphysiological dose, at different times, increase $\mathrm{TR} \alpha$ in adipocytes, 3T3-Ll (18).

It is known that TH may act by mechanisms other than the classical TR/Thyroid Hormone Responsive
Elements (TRE) (11). These mechanisms can be called non-classical or non-genomic because their initiation sites may be in the plasma membrane, like the activation of integrin $\alpha v \beta 3$ pathway, or in the cytoplasm, where the TH activates the mitogen-activated protein kinase (MAPK) or PI3K pathway. The initiation sites are proteins that are characterized as iodothyronine receptors $(13,21)$.

PI3K participates in a wide variety of cellular process, including intracellular trafficking, organization of the cytoskeleton, cell growth and transformation, and prevention of apoptosis $(24,25)$. PI3K has a role in differentiation of several cell lines $(26,27)$, including adipocytes. PI3K pathway activation by TH originates in the cytoplasm and involves TR $\alpha$ or TR $\beta$, resulting in specific gene transcription, including hypoxia inducing factor (HIF-l $\alpha$ ), glucose transporter 1 (GLUTl), calcineurin inhibitor (ZAKI4 $\alpha$ ) and leptin $(11,13,21,22)$. In this study, we used the LY294002 inhibitor to evaluate the need for PI3K pathway activation in modulating TR $\alpha$ mRNA by $\mathrm{T} 3$ during a one hour time period. Within the one hour period, the increased on TR $\alpha$ mRNA levels in the P and SI groups were suppressed by LY (Figure IA and B), proving that pathway activation is necessary for $\mathrm{T} 3$ to increase TR $\alpha$ levels. However, the inhibition of PI3K decreased basal TR $\alpha$ mRNA expression demonstrating a need this pathway to TR $\alpha$ mRNA expression in normal cell condition.

In addition, inhibition of protein synthesis with CHX completely blocked T3-induced increase in TR $\alpha$ mRNA levels (Figure 2A and B), showing that it is a gene indirectly up-regulated by $\mathrm{T} 3$, depending on the synthesis of a yet unknown protein. Moreover, CHX group (without T3) compared with control group decreases the basal levels of TR $\alpha$ mRNA, indicating the existence of certain short-lived proteins essential for the expression of this gene in normal conditions. Monden and cols. (28) demonstrated that CHX blocks the reduction in TR $\alpha$ levels caused by T3 in HTB- 185 cells, suggesting that down-regulation of TR $\alpha$ by T3 requires synthesis of a new protein.

In summary, during one hour of treatment, increased TR $\alpha$ levels in the P and SI groups were indirectly modulated by $\mathrm{T} 3$ and depended on activation of the PI3K pathway. This is the first study to demonstrate $\mathrm{TR} \alpha$ modulation by $\mathrm{T} 3$ in a very short time period (one hour) and assess PI3K pathway activation by $\mathrm{TH}$ on this gene in adipocytes, 3T3-Ll. 
Acknowledgments: we are grateful to Sueli A. Clara, José C. Georgete, Mário B. Bruno, Camila R. C. Camacho and Keize Nagamati Junior for their technical support. We also would like to thank Dr. Luis C. O. Magalhães for the translation of the manuscript into English. This manuscript has been proofread by native English speakers with related background in BioMed Proofreading. We thank CAPES and Fapesp (\# 2010/16911-4) for financial support. The authors declare no conflicts of interest in the present study.

Funding: this work was supported by São Paulo Research Foundation (Fapesp), process number 2010/16911-4, and Coordenação de Aperfeiçoamento de Pessoal de Nível Superior (Capes).

Disclosure: no potential conflict of interest relevant to this article was reported.

\section{REFERENCES}

1. Darimont C, Gaillard D, Ailhaud G, Negrel R. Terminal differentiation of mouse preadipocyte cells: adipogenic and antimitogenic role of triiodothyronine. Mol Cell Endocrinol. 1993;98:67-73.

2. Ailhaud G, Grimaldi P, Negrel R. Cellular and molecular aspects of adipose tissue development. Annu Rev Nutr. 1992;12:207-33.

3. Oppenheimer JH, Schwartz HL, Lane JT, Thompson MP. Functional relationship of thyroid hormone-induced lipogenesis, lipolysis, and thermogenesis in the rat. J Clin Invest. 1991;87:125-32.

4. Santini F, Marsili A, Mammoli C, Valeriano R, Scartabelli G, Pelosini $C$, et al. Serum concentrations of adiponectin and leptin in patients with thyroid dysfunctions. J Endocrinol Invest. 2004;27:RC5-7.

5. Williams GR. Cloning and characterization of two novel thyroid hormone receptor beta isoforms. Mol Cell Biol. 2000;20:8329-42.

6. Macchia PE, Takeuchi Y, Kawai T, Cua K, Gauthier K, Chassande $O$, et al. Increased sensitivity to thyroid hormone in mice with complete deficiency of thyroid hormone receptor alpha. Proc Natl Acad Sci U S A. 2001;98:349-54.

7. Glass CK. Differential recognition of target genes by nuclear receptor monomers, dimers, and heterodimers. Endocr Rev. 1994;15:391-407.

8. Baumann CT, Maruvada P, Hager GL, Yen PM. Nuclear cytoplasmic shuttling by thyroid hormone receptors. Multiple protein interactions are required for nuclear retention. J Biol Chem. 2001;276:11237-45.

9. Hernandez A, Obregon MJ. Presence and mRNA expression ofT3 receptors in differentiating rat brown adipocytes. Mol Cell Endocrinol. 1996;121:37-46.

10. Bianco AC, Silva JE. Cold exposure rapidly induces virtual saturation of brown adipose tissue nuclear T3 receptors. Am J Physiol. 1988;255:E496-503.

11. Moeller LC, Broecker-Preuss M. Transcriptional regulation by nonclassical action of thyroid hormone. Thyroid Res. 2011;4 Suppl 1:S6.
12. Cheng SY, Leonard JL, Davis PJ. Molecular aspects of thyroid hormone actions. Endocr Rev. 2010;31:139-70.

13. Moeller LC, Dumitrescu AM, Refetoff S. Cytosolic action of thyroid hormone leads to induction of hypoxia-inducible factor-1alpha and glycolytic genes. Mol Endocrinol. 2005;19:2955-63.

14. Flores-Delgado G, Marsch-Moreno M, Kuri-Harcuch W. Thyroid hormone stimulates adipocyte differentiation of 3 T3 cells. Mol Cell Biochem. 1987;76:35-43.

15. Chawla A, Lazar MA. Induction of Rev-ErbA alpha, an orphan receptor encoded on the opposite strand of the alpha-thyroid hormone receptor gene, during adipocyte differentiation. J Biol Chem. 1993;268:16265-9.

16. Yen PM. Physiological and molecular basis of thyroid hormone action. Physiol Rev. 2001;81:1097-142.

17. Yoshida T, Monkawa T, Hayashi M, Saruta T. Regulation of expression of leptin mRNA and secretion of leptin by thyroid hormone in 3T3-L1 adipocytes. Biochem Biophys Res Commun. 1997;232:822-6.

18. de Oliveira M, Luvizotto R de A, Olimpio RM, de Sibio MT, Silva $\mathrm{CB}$, Conde SJ, et al. Modulation of thyroid hormone receptors, TR $\alpha$ and TR $\beta$, by using different doses of triiodothyronine (T3) at different times. Arq Bras Endocrinol Metabol. 2013;57:368-74.

19. de Oliveira M, Luvizotto Rde A, Olimpio RM, De Sibio MT, Conde $\mathrm{SJ}$, Biz Rodrigues Silva $\mathrm{C}$, et al. Triiodothyronine increases mRNA and protein leptin levels in short time in 3T3-L1 adipocytes by PI3K pathway activation. PLoS One. 2013;18;8(9):e74856.

20. Livak KJ, Schmittgen TD. Analysis of relative gene expression data using real-time quantitative PCR and the 2(-Delta Delta $C(T)$ ) method. Methods. 2001;25:402-8.

21. Cheng SY, Leonard JL, Davis PJ. Molecular aspects of thyroid hormone actions. Endocr Rev. 2010;31:139-70.

22. Green $H$, Meuth $M$. An established pre-adipose cell line and its differentiation in culture. Cell. 1974;3:127-33.

23. Jiang W, Miyamoto T, Kakizawa T, Sakuma T, Nishio S, Takeda $T$, et al. Expression of thyroid hormone receptor alpha in 3T3L1 adipocytes; triiodothyronine increases the expression of lipogenic enzyme and triglyceride accumulation. J Endocrinol. 2004;182:295-302.

24. Toker A, Cantley LC. Signalling through the lipid products of phosphoinositide-3-OH kinase. Nature. 1997;387:673-6.

25. Vanhaesebroeck B, Leevers SJ, Panayotou G, Waterfield MD. Phosphoinositide 3-kinases: a conserved family of signal transducers. Trends Biochem Sci. 1997;22:267-72.

26. Aubin D, Gagnon A, Sorisky A. Phosphoinositide 3-kinase is required for human adipocyte differentiation in culture. Int $\mathrm{J}$ Obes. 2005;29:1006-9.

27. Fang J, Ding $M$, Yang $L$, Liu LZ, Jiang BH. PI3K/PTEN/AKT signaling regulates prostate tumor angiogenesis. Cell Signal. 2007;19:2487-97.

28. Monden T, NakajimaY, Hashida T, Ishii S, Tomaru T, Shibusawa N, et al. Expression of thyroid hormone receptor isoforms downregulated by thyroid hormone in human medulloblastoma cells. Endocr J. 2006;53:181-7. 